\title{
HASIL GARUT (MARANTHA ARUNDINACEAE) PADA KEKERINGAN
}

\author{
Muhammad Bogi Oktafani ${ }^{1}$ ), Supriyono ${ }^{2}$ ), Mth Sri Budiastuti ${ }^{2}$ ) \\ 1) Mahasiswa S1 Program Studi Agroteknologi, Fakultas Pertanian, Universitas Sebelas Maret \\ 2) Staf Dosen Program Studi Agroteknologi, Fakultas Pertanian, Universitas Sebelas Maret \\ Kontak Penulis: muhammadbogi99@gmail.com
}

\begin{abstract}
Arrowroot (Marantha arundinaceae) is one of substitute food source of wheat flour and rice. Mostly arrowroot wildly grow in yard and forest untreated so its productivity is relatively low. During the dry season, water availaility drops, causing drought. The aim of this research is to determine the effect of drought stress on tuber yields of arrowroot. This research was conducted on March to September 2016 at the Faculty of Agriculture Land Experiment Field of Sebelas Maret University in Jumantono, Karanganyar. The study using a randomized completed block design (RCBD) and one research have one treatment factor. One treatment has 4 experimental levels and each level is repeated six times so that there are 24 experimental unit. Drought treatment consist of following levels; $100 \%$, $75 \%, 50 \%, 25 \%$ of field capacity. The research shows that arrowroot is a dry-resistant plant up to $25 \%$ and produces good growth and yield is indicated by tuber weight $(551,67 \mathrm{~g})$.
\end{abstract}

Keyword: arowroot, drougt condition

AGROTECHNOLOGY RESEARCH JOURNAL

Oktafani MB, Supriyono, Budiastuti S. 2017. Arrowroot (Marantha arundinaceae) yields on drought. Agrotech Res J. 1(2): 29-32.

Oktafani MB, Supriyono, Budiastuti S. 2017. Hasil garut (Marantha arundinaceae) pada kekeringan. Agrotech Res J. 1(2): 29-32.

\section{PENDAHULUAN}

Dewasa ini impor di Indonesia akan bahan pokok seperti terigu dan beras sangat tinggi sehingga dibutuhkan alternatif bahan pangan. Garut merupakan salah satu sumber bahan pangan potensial pengganti tepung terigu dan beras. Umbi garut memiliki kandungan karbohidrat yang tinggi sehingga potensial meningkatkan ketahanan pangan (Sukamto et al. 2010). Di Indonesia kebanyakan garut dibiarkan tumbuh liar tanpa perawatan sehingga produktivitas rendah. Banyak petani belum membudidayakan secara intensif tanaman garut dikarenakan pengetahuan rendah akan tanaman ini. Pengembangan garut secara intensif dari awal pengolahan tanah hingga pemanenan memiliki tujuan agar pertumbuhan serta hasil garut (umbi) dapat optimal. Tanaman ini mampu tumbuh pada tanah yang miskin dan hama penyakit relatif sedikit (Sukarsa 2011).

Faktor yang berpengaruh terhadap hasil garut yaitu ketersedian air tanaman. Kekurangan air merupakan permasalahan yang serius (Siahbidi et al. 2013). Budidaya garut sering dilakukan dibawah tegakan sehingga ketersediaan air relatif rendah. Musim kemarau menyebabkan ketersediaan air turun sehingga terjadi kekeringan. Kekeringan menyebabkan penurunan produktivitas tanaman karena terdapat gangguan fotosintesis tanaman yang memerlukan air (Solikhatun et al. 2005), sedangkan tanaman garut memerlukan curah hujan minimum 1500-2000 mm per tahun (Djaafar et al. 2007). Hasil garut pada beberapa tingkat kekeringan diteliti untuk memperoleh teknologi sehingga dapat membantu masyarakat dalam budidaya garut khususnya pada kondisi lingkungan yang terbatas.

\section{BAHAN DAN METODE PENELITIAN}

Penelitian ini dilaksanakan mulai bulan Maret 2016 sampai bulan September 2016 bertempat di Plastic House Lahan Percobaan Fakultas Pertanian Universitas Sebelas Maret Surakarta di Jumantono, Karanganyar. Bahan yang digunakan tanaman garut umur 6 bulan, tanah alfisol, air. Alat yang digunakan yaitu polibag ukuran $60 \times 60 \mathrm{~cm}$, cetok, cangkul, gembor, ember, oven, timbangan analitik, penggaris, jangka sorong dan alat tulis.

Rancangan penelitian yang digunakan adalah rancangan acak kelompok lengkap (RAKL) menggunakan Plastic House. Perlakuan kekeringan A1 $=100 \%$ kapasitas lapang,$A 2=75 \%$ kapasitas lapang, $\mathrm{A} 3=50 \%$ kapasitas lapang, $A 4=25 \%$ kapasitas lapang. Data pengamatan dianalisis menggunakan ANOVA pada $\alpha=0,05$ (taraf $5 \%$ ). Apabila data yang dianalisis menunjukkan berpengaruh nyata maka dilanjutkan dengan DMRT taraf $5 \%$. Variabel pengamatan meliputi: tinggi tanaman, jumlah daun, jumlah anakan, rasio akar tajuk, jumlah umbi per tanaman, berat umbi per tanaman, dan ukuran umbi per tanaman.

Perancangan penelitian yaitu dengan menggunakan polibag berukuran $30 \times 60 \mathrm{~cm}$ dan disusun pada jarak tanam $40 \times 40 \mathrm{~cm}$. Tanah alfisol dimasukkan ke dalam polibag dan ditanam tanaman garut. Tanaman garut diletakan di perlakuan penyiraman untuk kekeringan. 


\section{HASIL PEMBAHASAN}

\section{Komponen pertumbuhan tanaman}

Pemahaman tentang pertumbuhan tanaman merupakan modal penting dalam upaya penanganan tanaman dan lingkungannya untuk mendapatkan suatu hasil tinggi (Sitompul dan Guritno 1995). Menurut Islami et al. (1995) kekeringan mempengaruhi semua aspek pertumbuhan tanaman, yaitu proses fisiologi, biokimia tanaman dan menyebabkan terjadinya modifikasi anatomi serta morfologi tanaman.

Tabel 4 Hasil pertumbuhan garut akibat beberapa tingkat kekeringan

\begin{tabular}{lrrrr}
\hline \multirow{2}{*}{ Perlakuan Kekeringan } & \multicolumn{4}{c}{ Variabel Pengamatan } \\
\cline { 2 - 5 } & $\begin{array}{r}\text { Tinggi tanaman } \\
\text { umur 12 bulan } \\
(\mathrm{cm})\end{array}$ & $\begin{array}{r}\text { Jumlah Daun } \\
\text { umur 12 bulan } \\
\text { (unit) }\end{array}$ & $\begin{array}{r}\text { Jumlah Anakan } \\
\text { umur 12 bulan } \\
\text { (unit) }\end{array}$ & $\begin{array}{r}\text { Rasio Akar } \\
\text { Tajuk }\end{array}$ \\
\hline $100 \% \mathrm{KL}$ & $75,83^{\mathrm{ab}}$ & $66,66^{\mathrm{b}}$ & 13,33 & 0,7133 \\
$75 \% \mathrm{KL}$ & $90,41^{\mathrm{b}}$ & $59,66^{\mathrm{ab}}$ & 11,5 & 0,4533 \\
$50 \% \mathrm{KL}$ & $73,33^{\mathrm{a}}$ & $58,33^{\mathrm{ab}}$ & 12,16 & 0,6533 \\
$25 \% \mathrm{KL}$ & $79,16^{\mathrm{ab}}$ & $36,67^{\mathrm{a}}$ & 8 & 0,6600 \\
\hline
\end{tabular}

Keterangan: Angka dalam kolom diikuti huruf tidak sama menunjukan berbeda nyata pada uji Duncan (DMRT taraf $5 \%)$

Tinggi tanaman sangat sensitif terhadap kondisi lingkungan khususnya kekeringan. Tanaman yang berada dalam kondisi tercekam atau kekurangan air cenderung membatasi pertumbuhan dan produktivitas tanaman yang disebabkan adanya periode kering maupun curah hujan yang tak terduga sehingga diperlukannya pengairan yang teratur (Salisbury dan Ross 1995). Hasil analasis ragam menunjukan adanya pengaruh pada tinggi tanaman garut perlakuan kekeringan umur 12 bulan. Berdasarkan hasil uji beda garut umur 12 bulan terdapat perbedaan nyata pada perlakuan $75 \%$ terhadap $50 \%$ dan berbeda tidak nyata terhadap perlakuan $100 \%$ serta $25 \%$ kapasitas lapang. Tinggi tanaman dengan tinggi rata-rata tertinggi terdapat pada perlakua $75 \%$ kapasitas lapang sebesar $90,41 \mathrm{~cm}$ dan terendah yakni sebesar $73,33 \mathrm{~cm}$ pada perlakuan 50\% kapasitas lapang (tabel 4). Kekeringan mempengaruhi turunnya laju pertumbuhan secara cepat yang disebabkan pengikatan hara dalam tanah terhambat serta fotosintat yang dihasilkan sebagian besar ditranslokasikan untuk pembentukan umbi. Air selain sebagai pelarutan hara berperan juga dalam perpindahan hara dan fotosintesis. Ketika fotosintesis terganggu kinerja akan enzim akan menurun pula dikarenakan hasil dari fotosintesis untuk membentuk energi terganggu (Fitter dan Hay 1998).

Daun merupakan organ utama tanaman yang bertugas sebagai tempat menyerapan dan mengubah energi cahaya matahari melalui proses fotosintesis, yang hasil fotosintesis digunakan sebagai makanan yang peran dalam pertumbuhan dan perkembangan tanaman (Suryaningsih 2004). Hasil analisis ragaman menunjukan bahwa perlakuan beberapa tingkat kekeringan berperngaruh nyata terhadap garut umur 12 bulan. Hasil uji beda menunjukan garut umur 12 bulan terdapat beda nyata yakni pada perlakuan kapasitas lapang $100 \%$ dengan $25 \%$, dan berbeda tidak nyata pada perlakuan kapasitas lapang $50 \%$ serta $75 \%$ sedangkan untuk perlakuan kapasitas lapang $75 \%$ dan $50 \%$ tidak berbeda nyata (tabel 4). Jumlah daun tertinggi terdapat pada perlakuan $100 \%$ kapasitas lapang garut umur 12 bulan dengan rata-rata sebesar 66,66 helai daun dan untuk jumlah daun terendah terdapat pada perlakuan $25 \%$ kapasitas lapang umur garut 12 bulan dengan rata-rata sebesar 36,67 helai. Penurunan jumlah daun dikarenakan kekeringan menghambat proses pembelahan dan pembesaran. Kekeringan akan menurunkan jumlah daun per tanaman dibandingkan dengan dalam kondisi cukup air secara signifikan (Pervez et al. 2009).

Jumlah anakan merupakan perubahan tingkat perkembangan khususnya untuk mempertahankan hidup atau memperbanyak keturunan dari tanaman garut. Anakan merupakan tanaman baru yang tumbuh disekitar tanaman induk ataupun jauh dengan induknya. Jumlah anakan merupakan salah satu indikator pertumbuhan garut (Guritno dan Sitompul 1995). Berdasarkan hasil penelitian tidak ada pengaruh nyata pada beberapa perlakuan kekeringan yang diberikan ke tanaman garut terhadap jumlah anakan pada tanaman 12 bulan. Hasil penelitian menunjukan jumlah anakan tertinggi terdapat pada perlakuan $100 \%$ kapasitas lapang umur tanaman 12 bulan yaitu dengan rata rata sebesar 13,33 anakan. Jumlah anakan terendah terdapat pada perlakuan 25\% kapasitas lapang umur dengan rata rata sebesar 8 anakan (tabel 4). Hal ini dapat terjadi karena kondisi lingkungan lahan pertanian yang tidak terduga dari suhu hingga curah hujan pada beberapa bulan penelitian. Berbeda dengan pendapat Gardner et al. (1991) yang menyatakan bahwa kekeringan yang ringan dapat menurunkan laju pertumbuhan tanaman pada fase pembentukan anakan. Hal ini disebabkan kebutuhan tanaman akan cadangan makanan yang bekurang akibat penghambatan pendistribusian sehingga pembentukan anakan terhambat.

Rasio akar tajuk merupakan istilah yang biasanya dinyatakan sebagai perbandingan bobot kering antara akar dengan tajuk tanaman. Tanaman yang mempunyai biomassa tinggi maka menunjukan penyerapan hara juga besar dan proses pertumbuhan tanaman tersebut optimal (Nugroho 2013). Hasil analisis ragam menunjukan bahwa kekeringan tidak berpengaruh nyata terhadap rasio akar tajuk. Hasil penelitian juga menunjukan rata-rata rasio akar tajuk tertinggi yaitu pada perlakuan $100 \%$ kapasitas lapang sebesar 0,7133 sedangkan untuk rata-rata terendah terdapat pada perlakuan $75 \%$ kapasitas lapang sebesar 0,4533 . Hasil 
penelitian juga menunjukan kekeringan menurunkan pertambahan akar tajuk pada garut. Hal ini dikarenakan bahwa kekeringan menurunkan kadar asimilat yang dihasilkan dari proses fotosintesis, karena materi dari yang digunakan dalam proses fotosintesis terbatas. Kekeringan menyebabkan penurunan pertumbuhan akar dan bagian tanaman atas permukaan tanah, menurunkan laju fotosintesis dan transpirasi serta merusak asam amino, enzim dan protein lainnya yang merupakan bahan pertumbuhan yang sangat dibutuhkan tanaman (Pugnaire et al. 1999). Hal ini sesuai dengan penelitian Hanum et al. (2007) pada tanaman kedelai bahwa kekeringan menurunkan berat kering akar dan tajuk pada pemberian air $80 \%$ kapasitas lapang menjadi 40\% kapasitas lapang.

\section{Komponen hasil umbi}

Analisis pertumbuhan tanaman dapat membantu mengidentifikasi faktor pertumbuhan utama yang mengendalikan atau membatasi hasil. Hal ini sangat diperlukan dalam upaya memperbaiki hasil tanaman pada suatu lingkungan tertentu atau adaptasi tanaman pada beberapa lingkungan (Sitompul dan Guritno, 1995). Kekeringan merupakan hal yang sangat mempengaruhi hasil kualitas maupun kuantitas dari umbi

garut.

Tabel 5 Hasil umbi garut akibat beberapa tingkat kekeringan

Variabel Pengamatan

Perlakuan

Kekeringan

Bobot umbi per tanaman $(g)$
Jumlah umbi per tanaman (unit)

$$
\text { Panjang umbi (cm) }
$$

Diameter umbi $(\mathrm{cm})$

\begin{tabular}{lrrrr}
\hline $100 \% \mathrm{KL}$ & $382.50 \mathrm{ab}$ & 13.67 & 16.48 & 1.91 \\
$75 \% \mathrm{KL}$ & $261.67 \mathrm{a}$ & 8.50 & 17.73 & 2.03 \\
$50 \% \mathrm{KL}$ & $254.16 \mathrm{a}$ & 9.83 & 20.28 & 1.87 \\
$25 \% \mathrm{KL}$ & $551.67 \mathrm{~b}$ & 12.83 & 23.55 & 2.01 \\
\hline
\end{tabular}

Keterangan: Angka dalam kolom diikuti huruf tidak sama menunjukan berbeda nyata pada uji Duncan (DMRT taraf $5 \%$ )

Bobot umbi merupakan parameter hasil yang sering digunakan dalam pengamatan tentang produktivitas umbi. Hasil analisis ragam menunjukan pada perlakuan beberapa tingkat kekeringan berpengaruh nyata terhadap bobot umbi pertanaman. Rata-rata bobot umbi per tanaman tertinggi pada perlakuan 25\% kapasitas lapang yakni sebesar 551,66 g. Sedangkan rata-rata terendah pada perlakuan $50 \%$ kapasitas lapang yakni sebesar 254,16 g. Hasil uji beda menunjukan bobot umbi per tanaman saling berbeda nyata terhadap kekeringan yakni antara perlakuan $50 \%$ dan $75 \%$ kapasitas lapang dengan perlakuan 25\% kapasitas lapang. Perlakuan 100\% kapasitas lapang berbeda tidak nyata terhadap ketiga perlakuan. Pada tanaman Lotus glaber kekeringan tanaman akan mempengarui biji yang dihasilkan seperti jumlah biji per tanaman dan jumlah biji dalam pot (Clue et al. 2006). Pada kondisi kekeringan, pertumbuhan akar tanaman lebih tinggi dibandingkan dengan pertumbuhan tanaman bagian atas. Akar juga memiliki kemampuan bertahan yang lebih baik (Ai dan Toray 2013).

Jumlah umbi per tanaman digunakan sebagai indikator. Jumlah umbi per tanaman merupakan banyaknya umbi yang terdapat pada satu tanaman percobaan. Hasil analisi ragam menunjukan beberapa tingkat kekeringan tidak memberikan pengaruh nyata terhadap jumlah umbi per tanaman. Hasil penelitian menunjukan terdapat rata-rata terbanyak jumlah umbi per tanaman pada perlakuan kekeringan dengan 100\% kapasitas lapang yakni sebesar 13,66 umbi. Jumlah umbi terendah terdapat pada perlakuan $75 \%$ kapasitas lapang yakni sebesar 8,5 umbi (tabel 5). Hasil penelitian juga menunjukan kekeringan menurunkan jumlah dari umbi garut. Hal ini disebabkan kekeringan menyebabkan stomata tertutup karena penyerapan air yang kurang menyebabkan tekanan turgor sel menurun. Terjadinya penutupan stomata menyebabkan proses fisiologi terganggu khususnya proses fiksasi $\mathrm{CO}^{2}$ yang menghasilkan asimilat yang digunakan memenuhi kebutuhan hidup tanaman (Surtinah 2013)..

Panjang umbi merupakan salah satu parameter pengamatan yang sering digunakan dalam pengamatan ukuran umbi untuk menentukan kualitas dari umbi. Berdasarkan hasil analasis ragam beberapa tingkat kekeringan tidak berpengaruh nyata terhadap panjang umbi garut. Hasil penelitian menunjukan rata-rata tertinggi panjang umbi garut yakni sebesar $23,55 \mathrm{~cm}$ terdapat pada perlakuan $25 \%$ kekeringan. Sedangkan rata-rata terendah terdapat pada perlakuan $100 \%$ yakni sebesar 16,48 cm. Hal ini dikarenakan garut memiliki tingkat toleransi terhadap kekeringan sehingga hasil fotosintesis hanya akan didistribusikan ke dalam umbi sebagai cadangan makanan untuk bertahan hidup garut. Berbeda dengan pendapat Jatoi et al (2014) pada kacang tanah apabila kekurangan air akan mengambat proses deferensiasi sel, pembelaan sel, dan pembentangan sel pada jaringan meristematik sehingga mengurangi jumlah biji. Jumlah biji terbentuk sangat ditentukan oleh jumlah fotosintat yang dapat ditranslokasikan untuk pembentukan biji tersebut.

Kualitas umbi yang dihasilkan garut dapat dilihat dari diameter umbi umbi. Diameter umbi merupakan ukuran lingkar umbi. Hasil analisis ragam menunjukan beberapa tingkat kekeringan tidak berpengaruh nyata terhadap diameter umbi. Hasil penelitian menunjukan rata-rata diameter umbi terbesar yakni pada perlakuan $75 \%$ kapasitas lapang dengan besar $2,03 \mathrm{~cm}$. Rata-rata terendah terdapat pada perlakuan 50\% kapasitas lapang dengan besar diameter umbi yakni $1,87 \mathrm{~cm}$. Hal ini disebabkan dipengaruhi curah hujan yang cukup tinggi pada bulan kering yang sedang terjadi sehingga menyebabkan aerasi dalam tanah mengganggu pembelahan sel dalam proses pembentukan umbi 
(Alves dan Setter 2004) serta potensi garut yang mampu bertahan dalam beberapa tingkat kekeringan.

\section{KESIMPULAN DAN SARAN}

\section{Kesimpulan}

Berdasarkan hasil penelitian yang telah dilakukan, maka dapat disimpulkan bahwa garut adalah tanaman tahan kering sampai $25 \% \mathrm{KL}$ dan masih menghasilkan pertumbuhan serta hasil yang baik ditunjukan dengan bobot umbi $(551,67 \mathrm{~g})$.

\section{Saran}

Berdasarkan hasil penelitian diharap dapat memberikan informasi mengenai hasil garut terhadap kekeringan. Garut dapat ditanam pada kondisi kurang air sehingga sangat direkomendasikan sebagai tanaman tumpang sari khususnya sistem agroforestri.

\section{DAFTAR PUSTAKA}

Ai NS, Torey $P$ 2013. Karakter morfologi akar sebagai indikator kekurangan air pada tanaman . J Bioslogos 3(1):31-33

Alves A.A.C. and Setter. T.L. 2004. Response of cassava leaf area expansion to water deficit: cell proliferation, cell expansion and delayed development. Annals of Botany. 94: 605-613

Clue A, Fernandez GFL, Dietrich M. 2006. Drought stress conditions during seed development of narrowleaf birdsfoot trefoil (Lotus glaber) Influences Seed Production and Subsequent Dormancy And Germination. Journal Lotus New Letter. 36(2) : 5863. .

Djaafar, T.F., Sarjiman, S. Rahayu, Arlyna B.P., Murwati, Catur, P., Mujahit, M., Sulasmi, Sumisih, dan Murdiman. 2007. Pengkajian sistem usaha tanaman umbi-umbian spesifik lokasi untuk menunjang agroindustri. Laporan Kegiatan. Balai Pengkajian Teknologi Pertanian Yogyakarta.

Fitter AH dan Hay RKM. 1995. Fisiologi Lingkungan Tanaman. Penerjemah: Andani $S$ dan Purbayanti ED. UGM Press. Yogyakarta.

Gardner FP, RB Pearce adn RI Mitchell 1991. Pcichology of Crop Plants. Terjemahan Subiyanto dan Susilo (editor). Fisiologi Tanaman Budidaya. UI press Jakarta. 428 halaman.

Guritno B, Sitompul SM 1995. Analisis Pertumbuhan Tanaman. Gadjah Mada University Press. Yogyakarta.
Hanum C., W. Q. Muqnisjah, S. Yahya, D. Supandi, K. Idris dan A. Sahar. 2007. Pertumbuhan Akar Kedelai pada Cekaman Aluminium, Kekeringan dan Cekaman Ganda Aluminium dan Kekeringan. Journal Agritop. 26 (1) :13-18

Islami, Utomo T, Hadi W 1995. Hubungan Tanah, Air dan Tanaman. IKIP Semarang Press. Semarang.

Jatoi WA, Baloch M, Gul S. 2014. Heterosis for yield and traits in wheat under water stress conditions. J of An \& plant Sci. 24(1) : 252-261. URL: http://www.thejaps.org.pk/docs/v-24-1/37.pdf

Pervez MA, CM Ayub, HA Khan, MA Shahid, I Ashraf 2009. Effect of Drought Stress on Growth, Yield and Seed. Quality of tomato park. J Agri Sci. 46(3): 174178.

Pugnaire, F.I., L. Serrano dan J. Pardos. 1999. Constraints by water stress on plant growth. Dalam: Passarakli, M. (Ed.). Handbook of Plant and Crop Stress. 2nd edn, Revised and expanded. Marcel Dekker Inc, New York, Basel.

Salisbury FB and Ross CW 1995. Fisiologi Tumbuhan. Jilid 2. Terjemahan Diah $R$ Lukmana dan Sumaryono. ITB-Press. Bandung. Hal 293-295.

Siahbidi, Alireza P A, Abdolreza B, Reza N. 2013. Investigation of water deficit stress on yield and yield components of four soybean cultivar at different growth stages. International Journal of Biosciences. 3(8):104-109

Solikhatun, Anggarwulan E, Mudyantini W. 2005. Pengaruh ketersediaan air terhadap pertumbuhan dan kandungan bahan aktif saponin tanaman ginseng jawa (Talinum paniculatum Gaertn.). J Biofarmasi. 3(2):47-51.

Sukamto A, Fajarudin A, dan Albertus H. 2010. Pengaruh Oryzalin Terhadap Tingkat Ploidi Garut (Marantha arundinacea). J Bul.Litro 21(2): 93-102.

Sukarsa E. 2011. Tanaman Umbi Garut. http://www.bbpp-lembang.info/index.php/ arsip/artikel/artikel-pertanian/500-tanaman-umbigarut. Diakses pada tanggal 26 Januari 2016 pukul 6.18 WIB..

Surtinah 2013. Pengujian Kandungan Unsur Hara dalam Kompos yang Berasal dari Serasah Tanaman Jagung Manis (Zea mays saccharata). J Ilmiah Pertanian. 11(1): 16-25

Suryaningsih E 2004. Pengaruh macam ZPT dan media tanam terhadap pertumbuhan stek lada (Piper nigrum L). Skripsi S1 Fakultas Pertanian UNS. Surakarta. 